\title{
ANALISIS KOMPETENSI AGEN ASURANSI KASUS BUMI PUTERA SYARIAH PALEMBANG
}

\author{
Sahirrudin; Maya Panorama; Listiawati \\ UIN Raden Fatah Palembang \\ e-mail: sahirrudddin89@gmail.com
}

\begin{abstract}
The success of a company needs employees who are competent, experienced and strong. Islamic insurance companies certainly require employees who have knowledge about insurance in accordance with Islamic sharia principles. In the case of the Islamic insurance company Bumi Putera Palembang in 2015 to 2016 there are 40 insurance policyholders who worked in a government agency to terminate the employment relationship between the insurance and policyholders. This is because there is no transparency related to monthly installment payments that should be proven by a deposit or proof of receipt of payment in full by the field agent to the policy holder. This is not in line with the principles of Islamic insurance, namely avoiding the elements of gharar, maysir and usury. Islam emphasizes aspects of justice, likes and likes and togetherness faces risks in every effort and investment pioneered. This aspect is the concept offer to replace gharar, maysir and riba that have been happening in conventional institutions. The focus of research is on the competency of agents (wakalah) in the sharia Islamic Bumi Putera insurance company in the city of Palembang. The result is obtained from the conclusions of six indicators and evidenced by the table of productive reports of agents related to product marketing that human resources in agents /wakalah Bumi Putera Syariah Life Insurance have not described competency and professionalism. This can be seen from the lack of insurance products sold, attitudes to field issues and the achievement of the target customers determined by the company.
\end{abstract}

Keywords: Insurance Agent Competency, Bumi Putera Syariah

\section{Pendahuluan}

Perkembangan dan dukungan positif terlihat pada perkembangan ekonomi syariah ${ }^{1}$ di Indonesia dengan meningkatnya aset perbankan syariah dari Rp. 49,6 triliun pada 2008 menjadi Rp. 223 triliun pada Agustus 2013. Besarnya potensi produk syariah ini banyak perusahaan asuransi di Indonesia yang menawarkan produk syariah. Pertumbuhan industri asuransi syariah ditargetkan sebesar 35\% per tahun. Bahkan data terbaru dari Otoritas Jasa Keuangan (OJK) tercatat pertumbuhan aset total perasuransian syariah hingga Juni 2015 sebesar 24,06 \%. Penempatan dana investasi yang dikelola perasuransian syariah pun mengalami kenaikan sebesar 27,59\%. Sedangkan kontribusi (premi syariah) naik sebesar $15,59 \%$ dibandingkan periode yang sama pada tahun 2014 lalu. $^{2}$

\footnotetext{
${ }^{1}$ Secara sederhana, perkembangan itu dikelompokkan menjadi perkembangan industri keuangan syariah dan perkembangan ekonomi syariah non keuangan. Industri keuangan syariah relatif dapat dilihat dan diukur perkembangannya melalui data-data keuangan yang ada, sedangkan yang non keuangan perlu penelitian yang lebih dalam untuk mengetahuinya. Mahfuz, "Perkembangan Ekonomi Syariah Dan Peran Sertanya Dalam Pembangunan Indonesia", http://www.globalmulia.ac.id.

${ }^{2}$ Herry Ramadhani, "Prospek dan Tantangan Perkembangan Asuransi Syariah di Indonesia", AL-TIJARY, Vol.
} 
Kepercayaan dan juga optimisme akan kondisi ekonomi ke depan dapat juga mempengaruhi kinerja sumber daya manusia di industri keuangan syariah. Bisa dikatakan juga bahwa pertumbuhan keuangan syariah di Indonesia pelan tapi pasti karena pangsa pasar asuransi syariah sudah dan masih memperlihatkan pertumbuhannya. Meskipun minat pasar tinggi, sayangnya industri tumbuh dan berkembang lamban. Namun satu sisi harus di dukumg kinerja sumber daya manusia dari industri syariah sendiri harus memiliki performa yang cukup baik. $^{3}$

Pada tahun 2015 sampai dengan 2016 terdapat 40 pemegang polis asuransi yang bekerja sama dengan suatu lembaga pemeritahan melakukan pemutusan hubungan kerja antara pihak asuransi dan para pemegang polis hal itu dikarenakan tidak adanya tranparansi terkait pembayaran angsuran yang dibuktikan dengan tanda setor atau bukti kwitansi tanda lunas bayar. Hal ini tidak sejalan dengan prinsip yang dimiliki oleh asuransi syariah, yaitu menghindari unsur gharār, maysīir dan ribā. Islam menekankan aspek keadilan, suka sama suka dan kebersamaan menghadapi resiko dalam setiap usaha dan investasi yang dirintis. Aspek inilah yang menjadi tawaran konsep untuk menggantikan gharär, maysīr dan ribā yang selama ini terjadi di lembaga konvensional. ${ }^{4}$

Salah satu yang menjadi penunjang dalam tercapainya tujuan suatu perusahaan ialah pegawai yang bekerja dalam sistem yang ada di perusahaan tersebut, hal ini untuk menunjang kinerja seorang pegawai diperlukan pegawai yang memiliki kompetensi sesuai dengan kebutuhan yang diperlukan pada suatu perusahaan sehingga perusahaan tersebut dapat mencapai tujuannya dan membuktikan atau memperlihatkan potensi-potensi yang dimiliki perusahaan tersebut. ${ }^{5}$ Dalam hal ini kompetensi seseorang sangatlah berpengaruh terhadap kinerjanya dalam menjalankan tugas untuk membangun serta memajukan perusahaan.

Dalam mencapai kinerja pegawai, faktor sumber daya manusia sangat dominan pengaruhnya atau dengan kata lain aset penting dalam setiap organisasi adalah sumber daya manusia. Sumber daya manusia berfungsi sebagai penggerak sumber daya lain yang dimiliki oleh organisasi. Keberadaan sumber daya manusia dalam sebuah organisasi sangat penting dalam mewujudkan organisasi yang ideal dan perlu mendapat perhatian dan pengkajian yang lebih dalam karena mereka yang memprakarsai terbentuknya organisasi, mereka yang berperan membuat keputusan untuk semua fungsi, dan mereka juga yang berperan dalam menentukan kelangsungan hidup organisasi itu. ${ }^{6}$ Sumber daya manusia dalam organisasi juga harus diarahkan, dikoordinasikan serta memiliki keahlian atau kompeten untuk menghasilkan kontribusi terbaik bagi organisasi, sehingga apa yang menjadi tujuan organisasi dapat terwujud. ${ }^{7}$

Menurut Hadari Nawawi, ${ }^{8}$ yang dimaksud dengan sumber daya manusia meliputi tiga: (1) Sumber daya manusia adalah manusia yang bekerja di lingkungan suatu organisasi, disebut juga personel, tenaga kerja, pegawai atau karyawan, (2) Sumber daya manusia adalah

01, No. 01, Desember 2015.

${ }^{3}$ Sudarsono, Bank dan Lembaga Keuangan Syariah (Yogyakarta: Ekonisia, 2004), 167.

${ }^{4}$ Abdul Manan. Hukum Ekonomi Syariah Dalam perspektif Kewenangan Peradilan Agama (Jakarta: Kencana Prenada Media Grup, 2012), 237.

${ }^{5}$ Faustino Cardoso Gomes, Manajemen Sumber Daya Manusia (Yogyakarta: Andi, 2003), 1-2.

${ }^{6}$ Hasibuan Malayu, Manajemen Sumber Daya Manusia, (Jakarta: Bumi Aksara. 2001), 175.

${ }^{7}$ Sondang P. Siagian, Manajemen Sumber Daya Manusia, (Jakarta: Bumi Aksara, 2008), 181-185.

${ }^{8}$ Danang Sunyoto, Manajemen Sumber Daya Manusia (Yogyakarta: Caps, 2012), 3. 
potensi manusiawi sebagai penggerak organisasi dalam menwujudkan eksistensinya, (3) Sumber daya manusia yang berkompetensi adalah potensi yang merupakan aset dan berfungsi sebagai modal (non materil) di dalam organisasi bisnis, yang dapat mewujudkan menjadi potensi nyata secara fisik dan non fisik dalam mewujudkan eksistensi organisasi.

Banyaknya keunggulan yang dimiliki organisasi atau perusahaan, tidak akan dapat memaksimalkan produkivitas dan laba usaha tanpa adanya komunitas karyawan yang berkeahlian, kompeten, dan berdedikasi tinggi terhadap oragnisasi atau perusahaan. Keunggulan sekaligus kelemahan dari suatu organisasi bertumpu pada kualitas dan kuantitas sumber daya manusia yang terdapat di organisasi tersebut, apabila organisasi memiliki sumber daya manusia yang berkualitas yang memiliki kompetensi baik dan jumlah yang cukup maka itu akan mampu menjadi keunggulan. Begitu pula sebaliknya apabila kualitas sumber daya manusia yang dimiliki buruk maka itu akan menjadi kelemahan dari organisasi tersebut. ${ }^{9}$

Eric Zimmerman dalam bukunya Economic Principles and Problems menyebutkan bahwa sumber daya berkembang secara dinamis menurut irama kegiatan dan kebutuhan manusia. ${ }^{10}$ Dalam hal ini, faktor yang menentukan adalah sumber daya manusia yang menguasai ilmu pengetahuan dan teknologi sehingga sumber daya manusia yang dimiliki bekerja secara professional dan efektif. Justru sumber daya manusia inilah yang menetukan tujuan oraganisasi atau perusahaan bisnis dapat tercapai atau tidak.

Setiap organisasi perusahaan yang ingin tetap mampu berkiprah di dalam lingkungan yang semakin kompetitif harus memiliki Sumber daya manusia yang tangguh dan hebat. Sumber daya manusia yang kompeten sangat diperlukan dalam lingkungan yang kompetitif. ${ }^{11}$ Individu yang mempunyai kompetensi kerja yang baik tentu akan mudah untuk melaksanakan tanggung jawab pekerjaannya serta mampu menyesuaikan diri secara baik dengan lingkunganya. ${ }^{12}$ Indikator kompetensi dalam hal ini didasarkan bahwa kompetensi seseorang dapat dipengaruhi oleh latar belakang pengalaman. Misalnya, lamanya bekerja, jenis pekerjaan yang pernah dijalani, pengalaman pendidikan dan pelatihan, dan sebagainya. ${ }^{13}$

Dengan demikian Organisasi bisnis perusahaan memandang sumber daya manusia sebagai human capital, dimana kompetensi sumber daya manusia sebagai aset organisasi untuk mendorong eksistensi organisasi dalam lingkungan bisnis yang kompetitif.

\section{Pembahasan}

Kompetensi adalah kemampuan dan karakteristik dalam diri seseorang berupa pengetahuan, keterampilan, dan perilaku yang diperlukan dalam pelaksanaan tugasnya sehingga individu mampu menampilkan unjuk kerja yang tinggi dalam suatu pekerjaan. ${ }^{14}$

\footnotetext{
9 Burhanuddin Yusuf dan Nur Rianto Al Arif, Manajemen Sumber Daya Manusia di Lembaga Keuangan Syariah (Jakarta: Raja Grafindo Persada, 2015), 25 - 26.

${ }^{10}$ Samsudin Sadili, Manajemen sumber Daya Manusia (Bandung: Pustaka Setia, 2006), 22.

11 Andreas Lako dan Anna Sumaryati, "Optimalisasi Kinerja Korporasi Melalui Audit Kinerja Manajemen Sumber Daya Manusia”, Manajemen Usahawan Indonesia, No. 10, September 2002, 175.

${ }^{12}$ Pandji Anoraga, Pengantar bisnis. Pengelolaan Bisnis Dalam Era Globalisasi (Jakarta: Rineka Cipta, 2007), 183.

${ }^{13}$ Iriyanto, Human Resouce and Development (Surabaya: Insan Cendikia, 2001), 75.

${ }^{14}$ Peraturan Menteri Pendayagunaan Aparatur Negara dan Reformasi Birokrasi Rupblik Indonesia Nomor 20 Tahun 2017.
} 
Menurut Kubr A \& Proponenko, kompetensi terdiri atas technical competence dan behavioral competence. Technical competence berhubungan dengan pengetahuan, attitude, dan skill tentang struktur dan prosedur pekerjaan. Behavioral competence, berhubungan dengan keseluruhan aspek yang mempengaruhi seseorang berkomunikasi dan berinteraksi dengan orang lain. ${ }^{15}$

Selanjutnya peneliti mengelompokkan indikator kompetensi tersebut sebagaimana yang dikelompokkan oleh Spencer.

1. Semangat untuk berprestasi dan bertindak (achievement and action) yang meliputi kompetensi: a. Orientasi untuk berprestasi, b. Inisiatif.

a. Orientasi berprestasi

Orientasi untuk berprestasi merupakan derajat kepedulian atau upaya seseorang untuk berprestasi dalam pekerjaannya sehingga ia berusaha bekerja dengan baik atau di atas standar. Kompetensi ini direfleksikan dalam orientasi kepada hasil, efisiensi, standar, perbaikan, kewirausahaan, dan optimasi penggunaan sumber daya yaitu dorongan dalam diri seseorang untuk mengurangi ketidakpastian di lingkungan kerjanya. ${ }^{16}$

Indikator ini dapat terlihat pada tabel pertanyaan dan jawaban para wakālah di bawah ini:

Tabel 1.1 Wawancara

\begin{tabular}{|c|c|c|c|c|c|c|}
\hline \multirow[t]{2}{*}{ No } & \multirow{2}{*}{ Pertanyaan } & \multicolumn{5}{|c|}{ Jawaban Wakālah } \\
\hline & & I & II & III & IV & $\mathbf{V}$ \\
\hline 1. & $\begin{array}{l}\text { Apakah saudara } \\
\text { menginginkan } \\
\text { kenaikan jenjang } \\
\text { karir? }\end{array}$ & $\begin{array}{l}\text { Iya saya } \\
\text { sangat } \\
\text { menging } \\
\text { inkanny } \\
\text { a }\end{array}$ & $\begin{array}{l}\text { Iya, akan } \\
\text { tetapi } \\
\text { saya tidak } \\
\text { percaya } \\
\text { diri, } \\
\text { karena } \\
\text { saya } \\
\text { sudah tua }\end{array}$ & $\begin{array}{l}\text { Tidak } \\
\text { saya tidak } \\
\text { mengingi } \\
\text { nkannya }\end{array}$ & $\begin{array}{l}\text { Kalau } \\
\text { sesuai } \\
\text { dengan } \\
\text { targer yang } \\
\text { tercapai } \\
\text { kenapa } \\
\text { tidak }\end{array}$ & $\begin{array}{l}\text { Iya saya } \\
\text { mengingink } \\
\text { annya }\end{array}$ \\
\hline 2. & $\begin{array}{l}\text { Berapa banyak } \\
\text { target yang ibu } \\
\text { capai untuk } \\
\text { mendapatkan } \\
\text { nasabah dalam } \\
\text { sebulan? }\end{array}$ & $\begin{array}{l}\text { Saya } \\
\text { ingin } \\
\text { mendap } \\
\text { atkan } 50 \\
\text { juta } \\
\text { perbulan }\end{array}$ & $\begin{array}{l}\text { Belum } \\
\text { ada target }\end{array}$ & $\begin{array}{l}4 \text { orang } \\
\text { saja } \\
\text { dalam } \\
\text { satu bulan }\end{array}$ & $\begin{array}{l}\text { Sebanyak- } \\
\text { banyaknya }\end{array}$ & $\begin{array}{l}\text { Saya ingin } \\
\text { mendapatk } \\
\text { an nasabah } \\
\text { sebanyak } \\
\text { banyaknya }\end{array}$ \\
\hline
\end{tabular}

Orientasi berprestasi adalah keinginan untuk mencapai target yang melebihi standar yang telah ditetapkan oleh perusahaan. Kenaikan jenjang karir tentunya diimpikan setiap orang, akan tetapi tentunya mempunyai standar yang harus dicapai. Pada perusahaan asuransi syariah Bumi Putera untuk menjadi agency supervisor (di

\footnotetext{
${ }^{15}$ Iriyanto, Human Resouce and Development, 75.

${ }^{16}$ Umi Narimawati, Riset Manajemen Sumber Daya Manusia (Jakarta: Agung Media, 2007), 78.
} 
atas agen) maka wakālah diwajibkan untuk mendapatkan 10 orang nasabah dalam tiap bulannya. ${ }^{17}$

Dari tabel di atas dapat kita lihat bahwa meskipun mayoritas wakālah mempunyai keinginan untuk mendapatkan jenjang karir yang lebih baik akan tetapi dari hasil wawancara yang telah peneliti lakukan ditemukan bahwa wakālah II, IV, dan $\mathrm{V}$ belum mempunyai target pasti untuk mendapatkan nasabah dalam tiap bulannya. ${ }^{18}$ Padahal jumlah target yang pasti dalam mendapatkan nasabah akan menentukan semangat dalam bekerja, memotivasi diri serta mempengaruhi kesuksesan seseorang. ${ }^{19}$ Ini juga disebabkan karena minimnya persaingan kerja sesama wakālah, kurangya motivasi dari perusahaan, usia yang sudah kurang produktif, serta tidak ada kesanggupan dari agen untuk memenuhi standar apabila ingin menaikkan jenjang karir. ${ }^{20}$

b. Inisiatif

Hasil penelitian Goleman menunjukkan bahwa kemampuan terbesar yang mempengaruhi kesuksesan seseorang dalam bekerja adalah empati, disiplin diri dan inisiatif yang dikenal dengan nama kecerdasan emosional. ${ }^{21}$ Insiatif yaitu keinginan atau derajat usaha untuk bertindak melebihi yang di harapkan oleh pekerjaan, melakukan sesuatu tanpa menunggu perintah lebih dulu. Tindakan itu dilakukan untuk memperbaiki atau meningkatkan hasil pekerjaan dan menciptakan peluangpeluang baru secara proaktif. Pencarian dan pengumpulan informasi diartikan pula sebagai kemampuan memahami sesuatu secara lebih mendalam merujuk kepada besarnya usaha seseorang untuk mencari dan mengumpulkan informasi bagi peningkatan kualitas keputusan, dan tindakan berdasarkan informasi yang akurat serta pengalaman atas kondisi lingkungan. ${ }^{22}$

Tabel 1.2 Wawancara

\begin{tabular}{|c|c|c|c|c|c|c|}
\hline \multirow[t]{2}{*}{ No } & \multirow{2}{*}{ Pertanyaan } & \multicolumn{5}{|c|}{ Jawaban Wakālah } \\
\hline & & $\mathbf{I}$ & II & III & IV & $\mathbf{V}$ \\
\hline 1. & $\begin{array}{l}\text { Bagaimana cara } \\
\text { saudara } \\
\text { mengatasai } \\
\text { tekanan jika } \\
\text { nasabah ingin } \\
\text { memutuskan } \\
\text { polis? }\end{array}$ & $\begin{array}{l}\text { Saya } \\
\text { berikan } \\
\text { solusi, } \\
\text { menjelaskan } \\
\text { bahwa } \\
\text { asuransi ini } \\
\text { bermanfaat, } \\
\text { dan } \\
\text { memberikan }\end{array}$ & $\begin{array}{l}\text { Saya akan } \\
\text { tetap } \\
\text { memberik } \\
\text { an } \\
\text { pengertia } \\
\text { n, atau } \\
\text { langsung } \\
\text { dikejar } \\
\text { kerumah }\end{array}$ & $\begin{array}{l}\text { Saya akan } \\
\text { menjelask } \\
\text { an ulang } \\
\text { tentang } \\
\text { manfaat } \\
\text { asuransi }\end{array}$ & $\begin{array}{l}\text { Saya akan } \\
\text { mengalih } \\
\text { kan ke } \\
\text { premi } \\
\text { yang lebih } \\
\text { kecil }\end{array}$ & $\begin{array}{l}\text { Mencoba } \\
\text { untuk } \\
\text { memperta } \\
\text { hankan }\end{array}$ \\
\hline
\end{tabular}

${ }^{17}$ Wawancara pada tanggal 17 Mei 2018.

18 Wawancara pada tanggal 12 Mei 2018.

${ }^{19}$ Lisda Rahmasari, "Pengaruh Kecerdasan Intelektual, Kecerdasan Emosi dan Kecerdasan Spiritual Terhadap

Kinerja Karyawan”, Majalah Ilmiah INFORMATIKA, Vol. 3, No. 1, Januari 2012, 2.

${ }^{20}$ Wawancara pada tanggal 12 Mei 2018 .

${ }^{21}$ Lisda Rahmasari, Pengaruh Kecerdasan Intelektual, 2.

${ }^{22}$ Umi Narimawati, Riset Manajemen Sumber Daya Manusia, 78. 


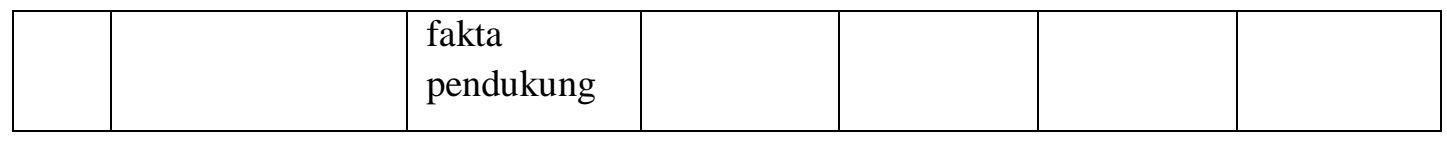

Indikator ini dapat dilihat apabila wakālah mendapatkan tekanan kasus seperti nasabah yang ingin memutuskan polis asuransi, ada beberapa wakālah yang langsung mendatangi rumah nasabah baik itu mendengarkan keluhan, memberikan solusi, tak jarang pula wakālah ikut membantu dalam urusan rumah tangga, misalnya mencuci piring sambil menjelaskan kembali manfaat asuransi dan memberikan fakta pendukung seperti piagam-piagam penghargaan dari perusahaan, surat klaim, dan Bumi Putra award. ${ }^{23}$

Dari jawaban wakālah, maka dapat disimpulkan wakālah I, II lebih unggul dibandingkan dengan wakālah yang lainnya. Hal ini dikarenakan bahwa inisiatif adalah kemampuan memahami dan mencari suatu informasi dari nasabah alasan ingin memutuskan polis, kemampuan ini lebih kepada kemampuan untuk mendengarkan keluhan dari nasabah sehingga akan didapatkan keputusan yang tepat dan menciptakan peluang baru untuk wakālah.

2. Kemampuan pelayanan meliputi orientasi pada kepuasan pelanggan.

Pada dasarnya asuransi adalah bentuk bisnis jasa di mana setiap pengusaha perasuransian akan berusaha memberikan layanan produk atau jasa yang maksimal bagi para pelanggannya, yang dapat dilakukan melalui dimensi-dimensi kualitas pelayanan (reliability, responsiveness, assurance, emphaty dan tangible). Kualitas jasa harus dimulai dari kebutuhan pelanggan yang berakhir dengan kepuasan pelanggan. Kepuasan pelanggan sangat penting bagi setiap organisasi namun beberapa studi menunjukkan bahwa memuaskan pelanggan saja tidak cukup karena tidak ada jaminan bahwa pelanggan yang puas akan menjadi pelanggan yang loyal. Hal ini pula yang dapat dijadikan pedoman oleh perusahaan agar konsumen dapat mempercayai produk yang ditawarkan dan melakukan pembelian ulang pada perusahaan tersebut, banyak perusahaan yang mengandalkan kepuasan konsumen sebagai jaminan keberhasilan dikemudian hari tetapi kemudian kecewa mendapati bahwa para konsumennya yang merasa puas dapat membeli produk pesaing tanpa ragu-ragu. ${ }^{24}$ Orientasi pada kepuasan pelanggan merupakan kemauan untuk membantu dan melayani kebutuhan atau harapan pelanggan/orang lain. ${ }^{25}$

Tabel 1.3 Wawancara

\begin{tabular}{|l|c|c|c|c|c|c|}
\hline \multirow{2}{*}{ No } & \multirow{2}{*}{ Pertanyaan } & \multicolumn{5}{|c|}{ Jawaban Wakālah } \\
\cline { 3 - 7 } & & \multicolumn{2}{|c|}{ I } & II & \multicolumn{1}{c|}{ IV } & V \\
\hline 1. & $\begin{array}{l}\text { Apa yang saudara } \\
\text { lakukan agar }\end{array}$ & $\begin{array}{l}\text { saya berikan } \\
\text { contoh kalau }\end{array}$ & $\begin{array}{l}\text { Saya akan } \\
\text { meminjamk }\end{array}$ & $\begin{array}{l}\text { Penjelasan } \\
\text { yang }\end{array}$ & $\begin{array}{l}\text { Menginfor } \\
\text { masikan }\end{array}$ & $\begin{array}{l}\text { Memenuhi } \\
\text { kebutuhan }\end{array}$ \\
\hline
\end{tabular}

\footnotetext{
${ }^{23}$ Wawancara pada 12 Mei 2018.

24 Steven Darwin dan Yohanes Sondang Kunto, “Analisis Pengaruh Kualitas Layanan Terhadap Loyalitas Pelanggan Dengan Kepuasan Dan Kepercayaan Pelanggan Sebagai Variabel Intervening Pada Asuransi Jiwa Manulife Indonesia-Surabaya", Jurnal Manajemen Pemasaran Petra, Vol 2, No.1 (2014).

${ }^{25}$ Moenir HAS, Manajemen Pelayaan Umum di Indonesia (Jakarta: Bumi Aksara, 1995), 229.
} 


\begin{tabular}{|c|c|c|c|c|c|c|}
\hline & $\begin{array}{l}\text { dapat } \\
\text { menumbuhkan } \\
\text { kepercayaan } \\
\text { pelanggan }\end{array}$ & $\begin{array}{l}\text { ada yang } \\
\text { mau klaim } \\
\text { saya berikan } \\
\text { surat } \\
\text { klaimnya, } \\
\text { dan diantar } \\
\text { langsung ke } \\
\text { kantor }\end{array}$ & $\begin{array}{l}\text { an buku } \\
\text { produk, dan } \\
\text { memberika } \\
\mathrm{n} \text { alamat } \\
\text { kantor, dan } \\
\text { gaya hidup } \\
\text { tidak } \\
\text { bermewaha } \\
\mathrm{n}\end{array}$ & $\begin{array}{l}\text { excelent } \\
\text { akan } \\
\text { produk }\end{array}$ & $\begin{array}{l}\text { bahwa } \\
\text { perusahaan } \\
\text { ditempat } \\
\text { kita adalah } \\
\text { perusahaan } \\
\text { yang tertua } \\
\text { dan selalu } \\
\text { terdepan }\end{array}$ & nasabah \\
\hline 2. & \begin{tabular}{lr}
\multicolumn{2}{l}{ Apa yang saudara } \\
lakukan \\
nasabah \\
kepada & tertarik \\
yang ditawarkan?
\end{tabular} & $\begin{array}{l}\text { Saya akan } \\
\text { membantun } \\
\text { ya jika } \\
\text { nasabah } \\
\text { dalam } \\
\text { kesulitan, } \\
\text { dan bergaul } \\
\text { dengan } \\
\text { orang } \\
\text { tersebut }\end{array}$ & $\begin{array}{l}\text { Saya akan } \\
\text { bantu } \\
\text { nasabah } \\
\text { sesuai } \\
\text { dengan } \\
\text { yang ia } \\
\text { senangi, } \\
\text { dan } \\
\text { didekati } \\
\text { secara } \\
\text { sosialisasi }\end{array}$ & $\begin{array}{l}\text { Pelayanan } \\
\text { informasi } \\
\text { produk dan } \\
\text { after } \\
\text { salesnya } \\
\text { juga }\end{array}$ & $\begin{array}{l}\text { Memberika } \\
\mathrm{n} \text { sovenir } \\
\text { dari } \\
\text { perusahaan }\end{array}$ & $\begin{array}{l}\text { Saya } \\
\text { jelaskan } \\
\text { dengan } \\
\text { detail }\end{array}$ \\
\hline
\end{tabular}

Dari jawaban wakālah di atas dapat dilihat wakālah I dan II secara konsisten berkompeten dalam hal untuk kepuasan pelanggan, kemampuan mengerti memahami sikap yang tidak terkatakan atau body language dari nasabah, wakālah I dan II tidak selalu harus menjadi orang yang didengarkan akan tetapi lebih kepada memahami dan mendengarkan keluhan dan sikap yang tersirat dari nasabah.

Wakālah I dan II tersebut tidak segan untuk langsung turun tangan ikut membantu nasabah jika dalam kesulitan, misalnya dengan meminjamkan uang ketika nasabah mengalami kesulitan ekonomi. Wakālah juga meminjamkan buku-buku produk perusahaan agar nasabah bisa membaca dan memahami sendiri serta memberikan alamat kantor untuk dapat meyakinkan dan dapat menumbuhkan kepercayaan nasabah.

Wakālah III, IV, V lebih cenderung untuk menjelaskan saja tentang produk dan belum sampai pada tahap mendengarkan dan memahami keluhan-keluhan dari nasabah. ${ }^{26}$ Hal ini membuktikan bahwa indikator kemampuan pelayanan kepuasan pelanggan yang berorientasi pada kepuasan pelanggan yang merupakan kemauan untuk membantu dan melayani kebutuhan atau harapan pelanggan belum sepenuhnya dimiliki oleh para wakālah.

3. Kemampuan mempengaruhi orang lain yang meliputi kompetensi mendukung dan mempengaruhi.

Kompetensi mendukung dan mempengaruhi merupakan kemampuan untuk membujuk, meyakinkan, mempengaruhi atau menimbulkan kesan baik pada orang lain sehingga orang lain mau mendukung gagasannya.

\footnotetext{
${ }^{26}$ Wawancara pada 12 Mei 2018.
} 
Tabel 1.4 Wawancara

\begin{tabular}{|c|c|c|c|c|c|c|}
\hline \multirow[t]{2}{*}{ No } & \multirow{2}{*}{ Pertanyaan } & \multicolumn{5}{|c|}{ Jawaban Wakālah } \\
\hline & & $\mathbf{I}$ & II & III & IV & $\mathbf{V}$ \\
\hline 1. & $\begin{array}{ll}\text { Bagaimana } & \text { cara } \\
\text { saudara } & \\
\text { melakukan } & \\
\text { pendekatan } & \\
\text { terhadap } & \text { calon } \\
\text { nasabah? } & \end{array}$ & $\begin{array}{l}\text { Share info } \\
\text { terkait } \\
\text { asuransi, } \\
\text { mengajak } \\
\text { pergi jalan- } \\
\text { jalan, ada } \\
\text { hubungan } \\
\text { emosional, } \\
\text { menawarka } \\
\text { n produk } \\
\text { unggulan }\end{array}$ & $\begin{array}{l}\text { Bermain } \\
\text { kerumah } \\
\text { calon } \\
\text { nasabah }\end{array}$ & $\begin{array}{l}\text { Dengan } \\
\text { memberika } \\
\text { n gambaran } \\
\text { kebutuhan } \\
\text { akan } \\
\text { perlunya } \\
\text { berasuransi }\end{array}$ & $\begin{array}{l}\text { Terus } \\
\text { didatangi ke } \\
\text { rumahnya, } \\
\text { memberikan } \\
\text { sesuatu } \\
\text { kepada } \\
\text { nasabah } \\
\text { tersebut }\end{array}$ & $\begin{array}{l}\text { Mendatangi } \\
\text { kerumah } \\
\text { atau kantor }\end{array}$ \\
\hline
\end{tabular}

Kemampuan untuk mempengaruhi orang lain dan memberikan kesan baik tentu saja harus dimiliki oleh wakālah jika ingin mendapatkan nasabah. Wakālah I, II, IV, V sering bertandang kerumah nasabah untuk membujuk dan meyakinkan agar calon nasabah dapat bergabung. Bahkan wakālah tersebut memberikan kesan baik berupa pemberian sesuatu, sampai mengajak calon nasabah untuk refreshing seperti bernyanyi di salah satu mall di Palembang. ${ }^{27}$

4. Kemampuan manajerial yang meliputi kompetensi: a). Memberi dukungan, b). Kepemimpinan kelompok.

Kemampuan manajerial merupakan kemampuan mendorong pengembangan atau proses belajar orang lain.

a. Memberi dukungan

Tabel 1.5 Wawancara

\begin{tabular}{|l|l|l|l|l|l|l|}
\hline No & \multicolumn{2}{|c|}{ Pertanyaan } & \multicolumn{5}{|c|}{ Jawaban Wakālah } \\
\cline { 3 - 7 } & \multicolumn{1}{|c|}{ I } & \multicolumn{1}{|c|}{ II } & \multicolumn{1}{|c|}{ III } & V \\
\hline 1. & $\begin{array}{l}\text { Apakah saudara } \\
\text { pernah berbicar } \\
\text { atau bertukar } \\
\text { pengalaman } \\
\text { sesama teman? }\end{array}$ & Pernah & $\begin{array}{l}\text { Jarang } \\
\text { sekali }\end{array}$ & Pernah & Pernah & Iya \\
\hline 2. & $\begin{array}{l}\text { Jika ada salah satu } \\
\text { teman saudara } \\
\text { yang belum } \\
\text { mendapatkan } \\
\text { nasabah } \\
\text { bagaimanakah } \\
\text { sikap saudara? }\end{array}$ & $\begin{array}{l}\text { Memberik } \\
\text { semangat }\end{array}$ & $\begin{array}{l}\text { Mencari } \\
\text { bersama- } \\
\text { sama, } \\
\text { memberik } \\
\text { an solusi }\end{array}$ & $\begin{array}{l}\text { Saya } \\
\text { support } \\
\text { teman } \\
\text { saya }\end{array}$ & $\begin{array}{l}\text { Memberi } \\
\text { semangat } \\
\text { kepadany } \\
\text { a }\end{array}$ & $\begin{array}{l}\text { Membant } \\
\text { unya }\end{array}$ \\
\hline
\end{tabular}

27 Wawancara pada 12 Mei 2018. 
Indikator ini dapat terlihat ketika apakah para wakālah sering berbicara dan bertukar pengalaman sesama teman atau nasabah. Atau pernahkah para wakālah membantu teman sesama wakālah yang belum mendapatkan nasabah sama sekali.

Dari tabel di atas, jawaban wakālah sepertinya memuaskan, akan tetapi peneliti lihat di lapangan tidak adanya suasana saling bertukar cerita ataupun motivasi dari sesama teman. Ini terlihat ketika mereka dikantor mereka hanya melakuka transaksi menyetor hasil premi kemudian pulang. ${ }^{28}$ Ini membuktikan bahwa kurangnya motivasi sesama teman kerja, lemahnya komunikasi untuk berbagi informasi sampai kesenjangan perlakuan antara wakālah yang terjun langsung ke lapangan dengan wakālah yang stand by di kantor. ${ }^{29}$ Menurut Mathis dan Jackson Tiga faktor utama yang mempengaruhi kinerja individu adalah kemampuan individu untuk melakukan pekerjaan tersebut, tingkat usaha yang dicurahkan dan dukungan organisasi. ${ }^{30}$

Kemudian adalah kerjasama atau kemampuan seorang tenaga kerja untuk bekerja bersama dengan orang lain dalam menyelesaikan suatu tugas dan pekerjaan yang telah ditetapkan. ${ }^{31}$ Tentunya dukungan organisasi ini dan team work yang solid perlu diperhatikan untuk mendapatkan perusahaan yang dapat berlangsung lama untuk mensejahterakan karyawan.

b. Kepemimpinan kelompok

Merupakan kemampuan dan kemauan untuk berperan sebagai pemimpin kelompok, biasanya ditunjukkan dalam posisi otoritas formal.

Tabel 1.6 Wawancara

\begin{tabular}{|c|c|c|c|c|c|c|}
\hline \multirow[t]{2}{*}{ No } & \multirow{2}{*}{ Pertanyaan } & \multicolumn{5}{|c|}{ Jawaban Wakālah } \\
\hline & & I & II & III & IV & $\mathbf{V}$ \\
\hline 1. & $\begin{array}{lr}\text { Jika } & \text { terdapat } \\
\text { karyawan } & \text { yang } \\
\text { tidak } & \text { bekerja } \\
\text { dengan } & \text { baik apa } \\
\text { yang } & \text { saudara } \\
\text { lakukan? } & \end{array}$ & $\begin{array}{l}\text { Memotiva } \\
\text { si, visit to } \\
\text { home, } \\
\text { mengajak } \\
\text { untuk } \\
\text { refreshing }\end{array}$ & $\begin{array}{l}\text { Menasihat } \\
\text { inya }\end{array}$ & $\begin{array}{l}\text { menginga } \\
\text { tkannya }\end{array}$ & $\begin{array}{l}\text { ditegur } \\
\text { dengan } \\
\text { baik }\end{array}$ & $\begin{array}{l}\text { Memb } \\
\text { antuny } \\
\text { a }\end{array}$ \\
\hline
\end{tabular}

Dari tabel di atas dapat dilihat bahwa wakālah I dan V lebih cenderung mempunyai kemampuan untuk memotivasi, memberikan dukungan dan mengajak teman yang sedang tidak bekerja dengan baik untuk berekreasi. Kemampuan ini sangat penting dimiliki bagi wakālah yang ingin menjadi pemimpin dalam kelompoknya. Sementara wakālah II, III, dan IV cenderung menyikapi seadanya saja jika ada karyawan tidak berkerja dengan baik.

\footnotetext{
${ }^{28}$ Observasi di Perusahaan Asuransi Syariah Bumi Putera.

${ }^{29}$ Observasi di Perusahaan Asuransi Syariah Bumi Putera.

${ }^{30}$ Robert L Mathis dan John H Jackson, Manajemen Sumber Daya Manusia, Buku I (Jakarta; Salemba Empat, 2001), 56.

${ }^{31}$ Siswanto Sastrohadiwiryo, Manajemen Tenaga Kerja Indonesia (Jakarta: Bumi Aksara, 2003), 93.
} 
5. Kemampuan daya pikir meliputi kompetensi: (a). Berfikir analitik, (b). Keahlian teknis.

a. Berfikir Analitik

Kompetensi berfikir analitik yaitu kemampuan untuk memahami situasi atau permasalahan dengan cara menguraikannya menjadi bagian-bagian yang lebih rinci, atau kemampuan untuk mengamati implikasi suatu keadaan tahap demi tahap berdasarkan pemahaman dan pengetahuan masa lalu. ${ }^{32}$

Tabel 1.7 Wawancara

\begin{tabular}{|c|c|c|c|c|c|c|}
\hline \multirow[t]{2}{*}{ No } & \multirow{2}{*}{ Pertanyaan } & \multicolumn{5}{|c|}{ Jawaban Wakālah } \\
\hline & & $\mathbf{I}$ & II & III & IV & $\mathbf{V}$ \\
\hline 1. & $\begin{array}{l}\text { Apakah saudara } \\
\text { mempunyai } \\
\text { strategi untuk } \\
\text { meyakinkan } \\
\text { nasabah untuk } \\
\text { bekerja sama? }\end{array}$ & $\begin{array}{l}\text { Turun } \\
\text { kelapangan, } \\
\text { dengan cara } \\
\text { pendekatan } \\
\text { persuasif }\end{array}$ & $\begin{array}{l}\text { Iya } \\
\text { memberik } \\
\text { an contoh } \\
\text { jika } \\
\text { pejabat di } \\
\text { Indonesia } \\
\text { juga } \\
\text { bergabun } \\
\text { g di } \\
\text { asuransi }\end{array}$ & $\begin{array}{l}\text { Pendekatan } \\
\text { yang intes } \\
\text { terhadap } \\
\text { nasabah }\end{array}$ & $\begin{array}{l}\text { Memberik } \\
\text { an } \\
\text { keyakinan } \\
\text { kepada } \\
\text { nasabah } \\
\text { bahwa } \\
\text { asuransi } \\
\text { sangat } \\
\text { perlu } \\
\text { untuk } \\
\text { masa } \\
\text { depan } \\
\text { keluarga }\end{array}$ & Iya \\
\hline
\end{tabular}

Kompetensi ini dapat tercermin dari strategi-strategi yang dipakai oleh wakālah ketika ingin mendapatkan nasabah yang lebih sulit. Dari pertanyaan yang diajukan oleh peneliti didapatkan jawaban wakālah yang meyakinkan calon nasabah untuk ikut bergabung dengan memakai pendekatan yang intens, menjelaskan program unggulan beasiswa, dan bahkan mengatakan ada sebagian pejabat Indonesia yang ikut menjadi nasabah dari perusahaan asuransi ini. ${ }^{33}$

Keterampilan analitik ini adalah kemampuan memilah situasi menjadi beberapa bagian, mencari tahu apa yang perlu dilakukan dan merencanakan tindakan langkah demi langkah. ${ }^{34}$ Walaupun sesama wakălah akan tetapi keterampilan ini lebih banyak dimiliki oleh wakālah lapangan daripada wakālah yang mempunyai jabatan struktural di perusahaan.

b. Keahlian teknis

Yaitu penguasaan pengetahuan eksplisit berupa keahlian atau ketrampilan untuk menyelesaikan suatu pekerjaan serta motivasi untuk mengembangkan, mengunakan dan mendistribusikan pengetahuan dan ketrampilan kepada orang lain. ${ }^{35}$

\footnotetext{
${ }^{32}$ Hayes N, Managing Teams: A strategy for Success (London: Thomson, 2004), 96.

${ }^{33}$ Wawancara pada 12 Mei 2018.

${ }^{34}$ Mark Parkinson, Panduan Sukses Menghadapi Tes Psikometri (Psychometric Test) (Solo: Tiga Serangkai, 2004), 146.

${ }^{35}$ Hayes N, Managing Teams: A strategy for Success, 96.
} 
Keahlian teknis adalah pengetahuan wakālah tentang produk-produk asuransi dan manfaat kegunaannya produk asuransi tersebut. Produk asuransi syariah perusahaan Bumi Putera Syariah mempunyai tiga produk yaitu, Mitra Iqra Plus, Mitra Mabrur Plus, Mitra BP Link Syariah: Assalam, Taawun, Askum. ${ }^{36}$ Hasil wawancara dari para wakālah didapatkan bahwa para wakālah tidak banyak mengetahui kegunaan dan manfaat apa saja yang didapatkan dari produk-produk asuransi tersebut. Yang mereka ketahui hanyalah produk unggulan saja yang ditawarkan yang banyak diminati, yaitu produk Assalam. ${ }^{37}$

Tabel 1.8 Wawancara

\begin{tabular}{|c|c|c|c|c|c|c|}
\hline \multirow[t]{2}{*}{ No } & \multirow{2}{*}{ Pertanyaan } & \multicolumn{5}{|c|}{ Jawaban Wakālah } \\
\hline & & I & II & III & IV & $\mathbf{V}$ \\
\hline 1. & $\begin{array}{lr}\text { Sepanjang } & \text { yang } \\
\text { saudara } & \text { ketahui } \\
\text { ada berapa } & \text { produk } \\
\text { asuransi } & \text { yang } \\
\text { ditawarkan } & \text { oleh } \\
\text { perusahaan? } & \end{array}$ & $\begin{array}{l}\text { Ada tiga } \\
\text { produk }\end{array}$ & $\begin{array}{l}\text { Tidak } \\
\text { terlalu, } \\
\text { saya } \\
\text { hanya } \\
\text { mengetah } \\
\text { ui produk } \\
\text { tertentu } \\
\text { saja }\end{array}$ & $\begin{array}{l}\text { Iya saya } \\
\text { mengetah } \\
\text { ui }\end{array}$ & Iya & Iya \\
\hline
\end{tabular}

6. Efektivitas individu yang mencakup kompetensi-kompetensi : (a) pengendalian diri; (b) kepercayaan diri; (c) komitmen pada organisasi.

a. Pengendalian diri

Kompetensi pengendalian diri merupakan kemampuan mengendalikan emosi diri sehingga mampu mencegah perilaku negatif, khususnya ketika menghadapi tantangan atau penolakan dari orang lain atau pada saat bekerja di bawah tekanan. ${ }^{38}$

Tabel 1.9 Wawancara

\begin{tabular}{|c|c|c|c|c|c|c|}
\hline \multirow[t]{2}{*}{ No } & \multirow{2}{*}{ Pertanyaan } & \multicolumn{5}{|c|}{ Jawaban Wakālah } \\
\hline & & I & II & III & IV & $\mathbf{V}$ \\
\hline 1. & $\begin{array}{l}\text { Apa yang saudara } \\
\text { lakukan jika teman } \\
\text { kerja anda } \\
\text { memfitnah anda? }\end{array}$ & $\begin{array}{l}\text { Saya akan } \\
\text { melakuka } \\
\mathrm{n} \\
\text { pendekata } \\
\mathrm{n} \text { terhadap } \\
\text { teman } \\
\text { yang } \\
\text { memfitna }\end{array}$ & $\begin{array}{l}\text { Saya akan } \\
\text { menaseha } \\
\text { tinya }\end{array}$ & $\begin{array}{l}\text { Saya akan } \\
\text { mengklari } \\
\text { fikasi }\end{array}$ & $\begin{array}{l}\text { Saya akan } \\
\text { menanyak } \\
\text { annya } \\
\text { maksud } \\
\text { dari } \\
\text { fitnahann } \\
\text { ya }\end{array}$ & $\begin{array}{l}\text { Membiark } \\
\text { annya saja }\end{array}$ \\
\hline
\end{tabular}

\footnotetext{
${ }^{36}$ Dokumentasi Perusahaan Asuransi Syariah Bumi Putera.

${ }^{37}$ Wawancara pada 13 Mei 2018.

38 J Bhatnagar dan A Sharma, "The Indian Perspective of Strategic HR Roles and Organizational Learning Capability, Int. J. Hum. Res. Manage, Vol. 16, No. 9, 2005, 1711-1739.
} 


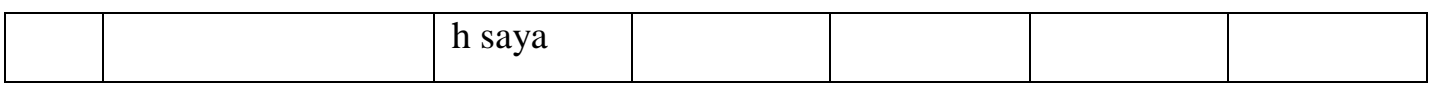

Kompetensi ini mencerminkan kemampuan seseorang untuk bisa memaafkan kesalahan diri sendiri dan kemauan untuk memperbaiki kesalahan tersebut. Dalam tahap pengendalian emosi rata-rata para jawaban dari wakālah adalah untuk membela diri. Padahal kemampuan pengendalian emosi bukan hanya sampai tahap membela diri melainkan ikhlas serta tahapan tertinggi adalah intropeksi diri, dan memperbaiki kesalahan tersebut.

b. Kepercayaan diri

Tabel 1.10 Wawancara

\begin{tabular}{|c|c|c|c|c|c|c|}
\hline \multirow[t]{2}{*}{ No } & \multirow{2}{*}{ Pertanyaan } & \multicolumn{5}{|c|}{ Jawaban Wakālah } \\
\hline & & I & II & III & IV & $\mathbf{V}$ \\
\hline 1. & $\begin{array}{l}\text { Jika ada nasabah } \\
\text { yang membatalkan } \\
\text { untuk bergabung } \\
\text { menjadi nasabah } \\
\text { bagaimanah sikap } \\
\text { saudara? }\end{array}$ & $\begin{array}{l}\text { Memperta } \\
\text { hankan } \\
\text { bahwa } \\
\text { asuransi } \\
\text { ini } \\
\text { bermanfa } \\
\text { at }\end{array}$ & $\begin{array}{l}\text { Dicarikan } \\
\text { solusi, } \\
\text { memberik } \\
\text { an } \\
\text { bantuan } \\
\text { jika dia } \\
\text { dalam } \\
\text { kesusahan }\end{array}$ & $\begin{array}{l}\text { Biasa } \\
\text { saja, dan } \\
\text { berbesar } \\
\text { hati akan } \\
\text { kegagalan }\end{array}$ & $\begin{array}{l}\text { Saya tetap } \\
\text { bersabar } \\
\text { dilain } \\
\text { waktu ada } \\
\text { yang lain }\end{array}$ & $\begin{array}{l}\text { Tetap } \\
\text { mencoba } \\
\text { dilain } \\
\text { waktu }\end{array}$ \\
\hline
\end{tabular}

Kompetensi ini adalah keyakinan seseorang pada kemampuannya untuk menyelesaikan suatu tugas atau pekerjaan. Dalam kompetensi ini tentunya tugas dari para wakālah adalah mencari nasabah sebanyak-banyaknya apabila menginginkan pendapatan yang besar serta kenaikan jenjang karir. Namun di lapangan para wakālah juga sering menjumpai penolakan dari calon nasabah untuk tidak ingin bergabung dalam perusahaan, tentunya ini adalah sebuah fenomena yang biasa dihadapi oleh wakālah. Berbagai sikap yang tercermin dari wakālah apabila nasabah ingin membatalkan untuk bergabung dari asuransi seperti wakālah III dan IV hanya bersabar, tetap mencoba di lain waktu, sampai hanya berbesar hati. ${ }^{39}$

Walaupun gagal meraih tujuan atau target, orang yang percaya diri tidak mudah menyerah karena mereka dapat berpikir positif terhadap segala sesuatu yang mereka hadapi. Gagal tidak membuat mereka menyalahkan diri sendiri dan menyerah karena mereka yakin akan kemampuan yang mereka miliki. Hal tersebut membuat mereka mampu bangkit lebih cepat dibandingkan orang yang tidak percaya diri ketika mengalami kegagalan. ${ }^{40}$

Pernyataan tersebut di atas juga didukung dengan laporan produktivitas wakālah tahun 2017 yang mengambarkan bahwa wakālah produktif atau tidak produktif. Data tersebut bisa dilihat pada tabel berikut:

\footnotetext{
${ }^{39}$ Wawancara pada 12 Mei 2018.

${ }^{40}$ Gregorius C. Alexander, "Pentingnya Rasa Percaya Diri dalam Dunia Kerja, dalam https://marketing.co.id.
} 
Tabel 1.11 Daftar Produktivitas Agen Bulan Januari 2017

DAFTAR PRODUKTIVITAS AGEN JANUARI 2017

\begin{tabular}{|c|c|c|c|c|c|c|c|c|c|c|}
\hline \multicolumn{2}{|c|}{$\begin{array}{l}\text { KANTOR } \\
\text { AGEN } \\
\text { PERIODE MULAI ASURANSI }\end{array}$} & $\begin{array}{l}\text { : KANTOR PEMASA } \\
\text { : SELURUH AGEN } \\
\text { : 01 JANUARI S.D } 3\end{array}$ & $\begin{array}{l}\text { ARAN SYARIAH PALEN } \\
11 \text { JANUARI } 2017\end{array}$ & NG & & & & & & \\
\hline \multirow{2}{*}{ No. } & \multirow{2}{*}{ NAMA AGEN } & \multirow{2}{*}{ NOMOR KANTOR } & \multirow{2}{*}{ NAMA KANTOR } & \multicolumn{6}{|c|}{ JENIS ASURANSI } & \multirow{2}{*}{$\begin{array}{c}\text { JUMLAH PREMI } \\
\text { BRUTO } \\
\end{array}$} \\
\hline & & & & MIP & MMP & BP LINK & ASSALAM & TA'AWUN & ASKUM & \\
\hline 1 & Wakalah I & 3040700 & $\begin{array}{l}\text { Kantor Pemasaran } \\
\text { Syariah Palembang }\end{array}$ & 0 & 0 & 0 & 1 & 0 & 0 & $100.000,00$ \\
\hline 2 & Wakalah II & 3040700 & $\begin{array}{l}\text { Kantor Pemasaran } \\
\text { Syariah Palembang }\end{array}$ & 1 & 0 & 0 & 0 & 0 & 0 & $500.000,00$ \\
\hline 3 & Wakalah III & 3040700 & $\begin{array}{l}\text { Kantor Pemasaran } \\
\text { Syariah Palembang }\end{array}$ & 0 & 0 & 0 & 0 & 0 & 0 & 0,00 \\
\hline 4 & Wakalah IV & 3040700 & $\begin{array}{l}\text { Kantor Pemasaran } \\
\text { Syariah Palembang }\end{array}$ & 0 & 0 & 0 & 0 & 0 & 0 & 0,00 \\
\hline \multirow[t]{2}{*}{5} & Wakalah V & 3040700 & $\begin{array}{l}\text { Kantor Pemasaran } \\
\text { Syariah Palembang }\end{array}$ & 0 & 0 & 0 & 0 & 0 & 0 & 0,00 \\
\hline & \multicolumn{3}{|c|}{ JUMLAH } & 1 & 0 & 0 & 1 & 0 & $\mathbf{0}$ & $600.000,00$ \\
\hline
\end{tabular}

Catatan:
\begin{tabular}{|c|l|l|}
\hline No. & \multicolumn{1}{|c|}{ JENIS ASURANSI } & \multicolumn{1}{c|}{ KODE } \\
\hline & MTRA IQRA PLUS & MIP \\
\hline & MITRA MABRU PLUS & MMP \\
\hline & MITRA BP LINK SYARIAH & BPLINK \\
\hline & & ASSALAM \\
\hline & & TA'AWUN \\
\hline & & ASKUM \\
\hline
\end{tabular}

Daftar Tabel di atas menggambarkan bahwa produktivitas agen yang memasarkan produk asuransi, di bulan Januari terjual satu produk yaitu jenis asuransi Mitra Iqra Plus dan Mitra BP Link Syariah Assalam sebesar Rp600.000,00. Syarat untuk jenjang karir agen mendapatkan premi asuransi maksimal 10 per/bulan. ${ }^{41}$

Tabel 1.12 Daftar Produktivitas Agen Bulan Februari 2017

DAFTAR PRODUKTIVITAS AGEN FEBRUARI 2017

\begin{tabular}{|c|c|c|c|c|c|c|c|c|c|c|}
\hline \multicolumn{2}{|c|}{$\begin{array}{l}\text { KANTOR } \\
\text { AGEN } \\
\text { PERIODE MULAI ASURANSI }\end{array}$} & \multicolumn{9}{|c|}{$\begin{array}{l}\text { : SELURUH AGEN } \\
: 01 \text { FEBRUARI S.D } 28 \text { FEBRUARI } 2017\end{array}$} \\
\hline \multirow{2}{*}{ No. } & \multirow{2}{*}{ NAMA AGEN } & \multirow{2}{*}{ NOMOR KANTOR } & \multirow{2}{*}{ NAMA KANTOR } & \multicolumn{6}{|c|}{ JENIS ASURANSI } & \multirow{2}{*}{$\begin{array}{c}\text { JUMLAH PREMI } \\
\text { BRUTO }\end{array}$} \\
\hline & & & & MIP & MMP & BP LINK & ASSALAM & TA'AWUN & ASKUM & \\
\hline 1 & Wakalah I & 3040700 & $\begin{array}{l}\text { Kantor Pemasaran } \\
\text { Syariah Palembang }\end{array}$ & 0 & 0 & 0 & 1 & 0 & 0 & $100.000,00$ \\
\hline 2 & Wakalah II & 3040700 & $\begin{array}{l}\text { Kantor Pemasaran } \\
\text { Syariah Palembang }\end{array}$ & 0 & 0 & 0 & 0 & 0 & 0 & 0,00 \\
\hline 3 & Wakalah III & 3040700 & $\begin{array}{l}\text { Kantor Pemasaran } \\
\text { Syariah Palembang }\end{array}$ & 0 & 0 & 0 & 0 & 0 & 0 & 0,00 \\
\hline 4 & Wakalah IV & 3040700 & $\begin{array}{l}\text { Kantor Pemasaran } \\
\text { Syariah Palembang }\end{array}$ & 0 & 0 & 0 & 0 & 0 & 0 & 0,00 \\
\hline \multirow[t]{2}{*}{5} & Wakalah V & 3040700 & $\begin{array}{l}\text { Kantor Pemasaran } \\
\text { Syariah Palembang }\end{array}$ & 4 & 0 & 0 & 18 & 0 & 0 & $4.800 .000,00$ \\
\hline & \multicolumn{3}{|c|}{ JUMLAH } & 4 & $\mathbf{0}$ & $\mathbf{0}$ & 19 & $\mathbf{0}$ & $\mathbf{0}$ & $4.900 .000,00$ \\
\hline
\end{tabular}

Catatan:
\begin{tabular}{|l|l|l|}
\hline No. & \multicolumn{1}{|c|}{ JENIS ASURANSI } & \multicolumn{1}{|c|}{ KODE } \\
\hline & MITRA IQRA PLUS & MIP \\
\hline & MIRA MABRU PLUS & MMP \\
\hline & MTRA BP LINK SYARIAH & BP LINK \\
\hline & & ASSALAM \\
\hline & & TA'AWUN \\
\hline & & ASKUM \\
\hline
\end{tabular}

Daftar Tabel di atas menggambarkan bahwa produktivitas agen yang memasarkan produk asuransi, di bulan Februari terjual sembilan belas produk, yaitu jenis asuransi Mitra Iqra Plus dan Mitra BP Link Syariah Assalam sebesar Rp. 4.900.000,00. Syarat untuk jenjang karir agen mendapatkan premi asuransi maksimal 10 per/bulan. ${ }^{42}$

${ }^{41}$ Wawancara pada 13 Mei 2018.

${ }^{42}$ Wawancara pada 29 Mei 2018. 
Tabel 1.13 Daftar Produktivitas Agen Bulan Maret 2017

DAFTAR PRODUKTIVITAS AGEN MARET 2017

\begin{tabular}{|c|c|c|c|c|c|c|c|c|c|c|}
\hline \multirow{3}{*}{\multicolumn{2}{|c|}{$\begin{array}{l}\text { KANTOR } \\
\text { AGEN } \\
\text { PERIODE MULAI ASURANSI }\end{array}$}} & \multicolumn{9}{|c|}{ : KANTOR PEMASARAN SYARIAH PALEMBANG } \\
\hline & & \multicolumn{9}{|c|}{ : SELURUH AGEN } \\
\hline & & \multicolumn{9}{|c|}{ : 01 MARET S.D 31 MARET 2017} \\
\hline \multirow{2}{*}{ No. } & \multirow{2}{*}{ NAMA AGEN } & \multirow{2}{*}{ NOMOR KANTOR } & \multirow{2}{*}{ NAMA KANTOR } & \multicolumn{6}{|c|}{ JENIS ASURANSI } & \multirow{2}{*}{$\begin{array}{c}\text { JUMLAH PREMI } \\
\text { BRUTO }\end{array}$} \\
\hline & & & & MIP & MMP & BP LINK & ASSALAM & TA'AWUN & ASKUM & \\
\hline & & & & & & & & & & \\
\hline 1 & Wakalah I & 3040700 & $\begin{array}{l}\text { Kantor Pemasaran } \\
\text { Syariah Palembang }\end{array}$ & 0 & 0 & 0 & 0 & 0 & 0 & 0,00 \\
\hline 2 & Wakalah II & 3040700 & $\begin{array}{l}\text { Kantor Pemasaran } \\
\text { Syariah Palembang }\end{array}$ & 0 & 0 & 0 & 0 & 0 & 0 & 0,00 \\
\hline 3 & Wakalah III & 3040700 & $\begin{array}{l}\text { Kantor Pemasaran } \\
\text { Syariah Palembang }\end{array}$ & 0 & 0 & 0 & 0 & 0 & 0 & 0,00 \\
\hline 4 & Wakalah IV & 3040700 & $\begin{array}{l}\text { Kantor Pemasaran } \\
\text { Syariah Palembang }\end{array}$ & 0 & 0 & 0 & 0 & 0 & 0 & 0,00 \\
\hline \multirow[t]{2}{*}{5} & Wakalah V & 3040700 & $\begin{array}{l}\text { Kantor Pemasaran } \\
\text { Syariah Palembang }\end{array}$ & 0 & 0 & 0 & 0 & 0 & 0 & 0,00 \\
\hline & \multicolumn{3}{|c|}{ JUMLAH } & 0 & 0 & 0 & 0 & 0 & 0 & 0,00 \\
\hline
\end{tabular}

Catatan:
\begin{tabular}{|l|l|l|}
\hline No. & \multicolumn{1}{|c|}{ JENIS ASURANSI } & \multicolumn{1}{c|}{ KODE } \\
\hline & MITRA IQRA PLUS & MIP \\
\hline & MITRA MABRU PLUS & MMP \\
\hline & MTRA BP LINK SYARIAH & BPLINK \\
\hline & & ASSALAM \\
\hline & & TA'AWUN \\
\hline & & ASKUM \\
\hline
\end{tabular}

Daftar Tabel di atas menggambarkan bahwa produktivitas agen yang belum produktif memasarkan produk asuransi, di bulan Maret tidak ada yang terjual sebesar Rp. 0,00. Syarat untuk jenjang karir agen mendapatkan premi asuransi maksimal 10 per/bulan.

Tabel 1.14 Daftar Produktivitas Agen Bulan April 2017 DAFTAR PRODUKTIVITAS AGEN APRIL 2017

\begin{tabular}{|c|c|c|c|c|c|c|c|c|c|c|}
\hline \multicolumn{2}{|c|}{$\begin{array}{l}\text { KANTOR } \\
\text { AGEN } \\
\text { PERIODE MULAI ASURANSI }\end{array}$} & \multicolumn{9}{|c|}{$\begin{array}{l}\text { : KANTOR PEMASARAN SYARIAH PALEMBANG } \\
\text { : SELURUH AGEN } \\
\text { : } 01 \text { APRIL S.D } 30 \text { APRIL } 2017\end{array}$} \\
\hline \multirow{2}{*}{ No. } & \multirow{2}{*}{ NAMA AGEN } & \multirow{2}{*}{ NOMOR KANTOR } & \multirow{2}{*}{ NAMA KANTOR } & \multicolumn{6}{|c|}{ JENIS ASURANSI } & \multirow{2}{*}{$\begin{array}{c}\text { JUMLAH PREMI } \\
\text { BRUTO }\end{array}$} \\
\hline & & & & MIP & MMP & BP LINK & ASSALAM & \begin{tabular}{|l|} 
TA'AWUN \\
\end{tabular} & ASKUM & \\
\hline 1 & Wakalah I & 3040700 & $\begin{array}{l}\text { Kantor Pemasaran } \\
\text { Syariah Palembang }\end{array}$ & 0 & 0 & 0 & 2 & 0 & 0 & $100.000,00$ \\
\hline 2 & Wakalah II & 3040700 & \begin{tabular}{|l} 
Kantor Pemasaran \\
Syariah Palembang
\end{tabular} & 0 & 0 & 0 & 1 & 0 & 0 & $50.000,00$ \\
\hline 4 & Wakalah IV & 3040700 & $\begin{array}{l}\text { Kantor Pemasaran } \\
\text { Syariah Palembang }\end{array}$ & 1 & 0 & 0 & 0 & 0 & 0 & $200.000,00$ \\
\hline \multirow[t]{2}{*}{5} & Wakalah V & 3040700 & $\begin{array}{l}\text { Kantor Pemasaran } \\
\text { Syariah Palembang }\end{array}$ & 0 & 0 & 0 & 4 & 0 & 0 & $200.000,00$ \\
\hline & \multicolumn{3}{|c|}{ JUMLAH } & 1 & 0 & 0 & 12 & 0 & 0 & $1.150 .000,00$ \\
\hline \multicolumn{11}{|c|}{ Catatan: } \\
\hline \multirow[t]{2}{*}{ No. } & JENIS ASURANSI & KODE & & & & & & & & \\
\hline & & ASKUM & & & & & & & & \\
\hline
\end{tabular}

Daftar Tabel di atas menggambarkan bahwa produktivitas agen yang memasarkan produk asuransi, di bulan April terjual tiga belas produk yaitu jenis asuransi Mitra Iqra Plus dan Mitra BP Link Syariah Assalam sebesar Rp. 1.150.000,00. Syarat untuk jenjang karir agen mendapatkan premi asuransi maksimal 10 per/bulan. ${ }^{43}$

\footnotetext{
${ }^{43}$ Wawancara pada 13 Mei 2018.
} 
Tabel 1.15 Daftar Produktivitas Agen Bulan Mei 2017

DAFTAR PRODUKTIVITAS AGEN MEI 2017

\begin{tabular}{|c|c|c|c|c|c|c|c|c|c|c|}
\hline \multicolumn{2}{|c|}{$\begin{array}{l}\text { KANTOR } \\
\text { AGEN } \\
\text { PERIODE MULAI ASURANSI }\end{array}$} & \multicolumn{9}{|c|}{$\begin{array}{l}\text { : SELURUH AGEN } \\
\text { : } 01 \text { MEI S.D } 31 \text { MEI } 2017\end{array}$} \\
\hline \multirow{2}{*}{ No. } & \multirow{2}{*}{ NAMA AGEN } & \multirow{2}{*}{ NOMOR KANTOR } & \multirow{2}{*}{ NAMA KANTOR } & \multicolumn{6}{|c|}{ JENIS ASURANSI } & \multirow{2}{*}{$\begin{array}{l}\text { JUMLAH PREMI } \\
\text { BRUTO }\end{array}$} \\
\hline & & & & MIP & MMP & BP LINK & ASSALAM & TA'AWUN & ASKUM & \\
\hline & & & & & & & & & & \\
\hline 1 & Wakalah I & 3040700 & $\begin{array}{l}\text { Kantor Pemasaran } \\
\text { Syariah Palembang }\end{array}$ & 0 & 0 & 0 & 2 & 0 & 0 & $100.000,00$ \\
\hline 2 & Wakalah II & 3040700 & $\begin{array}{l}\text { Kantor Pemasaran } \\
\text { Syariah Palembang }\end{array}$ & 0 & 0 & 0 & 0 & 0 & 0 & 0,00 \\
\hline 3 & Wakalah III & 3040700 & $\begin{array}{l}\text { Kantor Pemasaran } \\
\text { Syariah Palembang }\end{array}$ & 0 & 0 & 0 & 2 & 0 & 0 & $200.000,00$ \\
\hline 4 & Wakalah IV & 3040700 & $\begin{array}{l}\text { Kantor Pemasaran } \\
\text { Syariah Palembang }\end{array}$ & 2 & 0 & 0 & 5 & 0 & 0 & $400.000,00$ \\
\hline \multirow[t]{2}{*}{5} & Wakalah V & 3040700 & $\begin{array}{l}\text { Kantor Pemasaran } \\
\text { Syariah Palembang }\end{array}$ & 0 & 0 & 0 & 0 & 0 & 0 & 0,00 \\
\hline & \multicolumn{3}{|c|}{ JUMLAH } & 2 & 0 & 0 & 9 & 0 & 0 & $700.000,00$ \\
\hline
\end{tabular}

Catatan:
\begin{tabular}{|l|l|l|}
\hline No. & \multicolumn{1}{|c|}{ JENIS ASURANSI } & \multicolumn{1}{c|}{ KODE } \\
\hline & MITRA IQRA PLUS & MIP \\
\hline & MITRA MABRU PLUS & MMP \\
\hline & MITRA BP LINK SYARIAH & BPLINK \\
\hline & & ASSALAM \\
\hline & & TA'AWUN \\
\hline & & ASKUM \\
\hline
\end{tabular}

Daftar Tabel di atas menggambarkan bahwa produktivitas agen yang memasarkan produk asuransi, di bulan Mei terjual sebelas produk, yaitu jenis asuransi Mitra Iqra Plus dan Mitra BP Link Syariah Assalam sebesar Rp. 700.00,00. Syarat untuk jenjang karir agen mendapatkan premi asuransi maksimal 10 per/bulan.

Tabel 1.16 Daftar Produktivitas Agen Bulan Juni 2017 DAFTAR PRODUKTIVITAS AGEN JUNI 2017

\begin{tabular}{|c|c|c|c|c|c|c|c|c|c|c|}
\hline KAN & ITOR & : KANTOR PEMASA & ARAN SYARIAH PALE & ANG & & & & & & \\
\hline AGE & & : SELURUH AGEN & & & & & & & & \\
\hline PERI & IODE MULAI ASURANSI & : 01 JUNI S.D $30 \mathrm{JU}$ & JNI 2017 & & & & & & & \\
\hline$N O$ & NAMA AGEN & NOMOR KANTOR & NAMA KANTOR & & & JENIS A & SURANSI & & & JUMLAH PREMI \\
\hline INO. & INAIVIA AGEIN & NOUVIUK KAIVIOK & INAIVIA KAIVIUK & MIP & MMP & BP LINK & ASSALAM & TA'AWUN & ASKUM & BRUTO \\
\hline 1 & Wakalah I & 3040700 & $\begin{array}{l}\text { Kantor Pemasaran } \\
\text { Syariah Palembang }\end{array}$ & 1 & 0 & 0 & 1 & 0 & 0 & $350.000,00$ \\
\hline 2 & Wakalah II & 3040700 & $\begin{array}{l}\text { Kantor Pemasaran } \\
\text { Syariah Palembang }\end{array}$ & 0 & 0 & 0 & 0 & 0 & 0 & 0,00 \\
\hline 3 & Wakalah III & 3040700 & $\begin{array}{l}\text { Kantor Pemasaran } \\
\text { Syariah Palembang }\end{array}$ & 0 & 0 & 0 & 0 & 0 & 0 & 0,00 \\
\hline 4 & Wakalah IV & 3040700 & $\begin{array}{l}\text { Kantor Pemasaran } \\
\text { Syariah Palembang }\end{array}$ & 1 & 0 & 0 & 0 & 0 & 0 & $1.500 .000,00$ \\
\hline 5 & Wakalah V & 3040700 & $\begin{array}{l}\text { Kantor Pemasaran } \\
\text { Syariah Palembang }\end{array}$ & 0 & 0 & 0 & 0 & 0 & 0 & 0,00 \\
\hline & & JUMLAH & & 2 & 0 & 0 & 1 & 0 & 0 & $1.850 .000,00$ \\
\hline Catat & & & & & & & & & & \\
\hline \begin{tabular}{|l} 
No. \\
\end{tabular} & JENIS ASURANSI & KODE & & & & & & & & \\
\hline & MITRA IQRA PLUS & MIP & & & & & & & & \\
\hline & MITRA MABRU PLUS & MMP & & & & & & & & \\
\hline & MITRA BP LINK SYARIAH & BP LINK & & & & & & & & \\
\hline & & ASSALAM & & & & & & & & \\
\hline & & TA'AWUN & & & & & & & & \\
\hline & & ASKUM & & & & & & & & \\
\hline
\end{tabular}

Daftar Tabel di atas menggambarkan bahwa produktivitas agen yang memasarkan produk asuransi, di bulan Juni terjual dua produk, yaitu jenis asuransi Mitra Iqra Plus dan Mitra BP Link Syariah Assalam sebesar Rp. 1.850.000,00. Syarat untuk jenjang karir agen mendapatkan premi asuransi maksimal 10 per/bulan. 
Tabel 1.17 Daftar Produktivitas Agen Bulan Juli 2017

DAFTAR PRODUKTIVITAS AGEN JULI 2017

\begin{tabular}{|c|c|c|c|c|c|c|c|c|c|c|}
\hline \multicolumn{2}{|c|}{$\begin{array}{l}\text { KANTOR } \\
\text { AGEN } \\
\text { PERIODE MULAI ASURANSI }\end{array}$} & \multicolumn{9}{|c|}{$\begin{array}{l}\text { : SELURUH AGEN } \\
: 01 \text { JULI S.D } 31 \text { JULI } 2017\end{array}$} \\
\hline \multirow{2}{*}{ NO. } & \multirow{2}{*}{ NAMA AGEN } & \multirow{2}{*}{ NOMOR KANTOR } & \multirow{2}{*}{ NAMA KANTOR } & \multicolumn{6}{|c|}{ JENIS ASURANSI } & \multirow{2}{*}{$\begin{array}{c}\text { JUMLAH PREMI } \\
\text { BRUTO }\end{array}$} \\
\hline & & & & MIP & MMP & BP LINK & ASSALAM & TA'AWUN & ASKUM & \\
\hline & & & & & & & & & & \\
\hline 1 & Wakalah I & 3040700 & $\begin{array}{l}\text { Kantor Pemasaran } \\
\text { Syariah Palembang }\end{array}$ & 0 & 0 & 0 & 1 & 0 & 0 & $50.000,00$ \\
\hline 2 & Wakalah II & 3040700 & $\begin{array}{l}\text { Kantor Pemasaran } \\
\text { Syariah Palembang }\end{array}$ & 0 & 0 & 0 & 0 & 0 & 0 & 0,00 \\
\hline 3 & Wakalah III & 3040700 & $\begin{array}{l}\text { Kantor Pemasaran } \\
\text { Syariah Palembang }\end{array}$ & 4 & 0 & 0 & 0 & 0 & 0 & $4.800 .000,00$ \\
\hline 4 & Wakalah IV & 3040700 & $\begin{array}{l}\text { Kantor Pemasaran } \\
\text { Syariah Palembang }\end{array}$ & 0 & 0 & 0 & 0 & 0 & 0 & 0,00 \\
\hline \multirow[t]{2}{*}{5} & Wakalah V & 3040700 & $\begin{array}{l}\text { Kantor Pemasaran } \\
\text { Syariah Palembang }\end{array}$ & 2 & 0 & 0 & 1 & 0 & 0 & $700.000,00$ \\
\hline & \multicolumn{3}{|c|}{ JUMLAH } & 6 & 0 & 0 & 2 & 0 & 0 & $5.550 .000,00$ \\
\hline
\end{tabular}

Catatan:
\begin{tabular}{|l|l|l|}
\hline No. & \multicolumn{1}{|c|}{ JENIS ASURANSI } & \multicolumn{1}{c|}{ KODE } \\
\hline & MITRA IQRA PLUS & MIP \\
\hline & MTRA MABRU PLUS & MMP \\
\hline & MTRA BP LINK SYARIAH & BP LINK \\
\hline & & ASSALAM \\
\hline & & TA'AWUN \\
\hline & & ASKUM \\
\hline
\end{tabular}

Daftar Tabel di atas menggambarkan bahwa produktivitas agen yang memasarkan produk asuransi, di bulan Juli terjual delapan produk, yaitu jenis asuransi Mitra Iqra Plus dan Mitra BP Link Syariah Assalam sebesar Rp. 1.850.000,00. Syarat untuk jenjang karir agen mendapatkan premi asuransi maksimal 10 per/bulan.

Tabel 1.18 Daftar Produktivitas Agen Bulan Agustus 2017 DAFTAR PRODUKTIVITAS AGEN AGUSTUS 2017

\begin{tabular}{|c|c|c|c|c|c|c|c|c|c|c|}
\hline \multirow{2}{*}{\multicolumn{2}{|c|}{$\begin{array}{l}\text { KANTOR } \\
\text { AGEN } \\
\text { PERIODE MULAI ASURANSI }\end{array}$}} & \multicolumn{9}{|c|}{ : KANTOR PEMASARAN SYARIAH PALEMBANG } \\
\hline & & \multicolumn{9}{|c|}{ : SELURUH AGEN } \\
\hline No. & NAMA AGEN & NOMOR KANTOR & NAMA KANTOR & \multicolumn{6}{|c|}{ JENIS ASURANSI } & $\begin{array}{l}\text { JUMLAH PREMI } \\
\text { BRUTO }\end{array}$ \\
\hline & & & & & & & & & & \\
\hline 1 & Wakalah I & 3040700 & $\begin{array}{l}\text { Kantor Pemasaran } \\
\text { Syariah Palembang }\end{array}$ & 0 & 0 & 0 & 2 & 0 & 0 & $100.000,00$ \\
\hline 3 & Wakalah III & 3040700 & $\begin{array}{l}\text { Kantor Pemasaran } \\
\text { Syariah Palembang }\end{array}$ & 0 & 0 & 0 & 0 & 0 & 0 & 0,00 \\
\hline 4 & Wakalah IV & 3040700 & $\begin{array}{l}\text { Kantor Pemasaran } \\
\text { Syariah Palembang }\end{array}$ & 0 & 0 & 0 & 0 & 0 & 0 & 0,00 \\
\hline 5 & Wakalah V & 3040700 & \begin{tabular}{|l|} 
Kantor Pemasaran \\
Syariah Palembang
\end{tabular} & 0 & 0 & 0 & 0 & 0 & 0 & 0,00 \\
\hline \multirow{4}{*}{\begin{tabular}{|l|} 
No. \\
\end{tabular}} & MITRA BP LINK SYARIAH & BP LINK & & & & & & & & \\
\hline & & ASSALAM & & & & & & & & \\
\hline & & TA'AWUN & & & & & & & & \\
\hline & & ASKUM & & & & & & & & \\
\hline
\end{tabular}

Daftar Tabel di atas menggambarkan bahwa produktivitas agen yang memasarkan produk asuransi, di bulan Agustus terjual dua produk, yaitu jenis asuransi Mitra BP Link Syariah Assalam sebesar Rp. 100.000,00. Syarat untuk jenjang karir agen mendapatkan premi asuransi maksimal 10 per/bulan. 
Tabel 1.19 Daftar Produktivitas Agen Bulan September 2017 DAFTAR PRODUKTIVITAS AGEN SEPTEMBER 2017

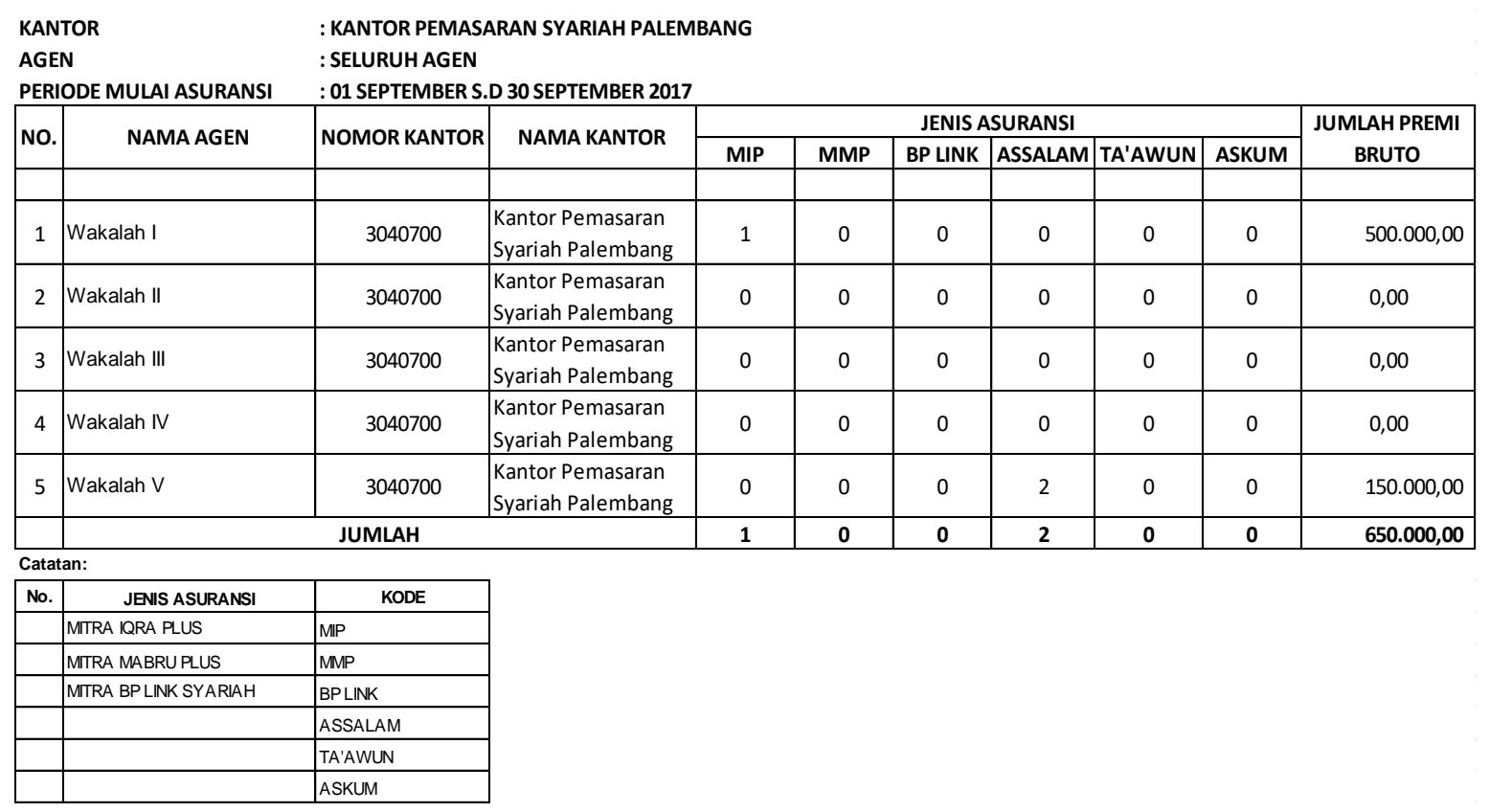

Daftar Tabel di atas menggambarkan bahwa produktivitas agen yang memasarkan produk asuransi, di bulan September terjual tiga produk, yaitu jenis asuransi Mitra BP Link Syariah Assalam sebesar Rp. 650.000,00. Syarat untuk jenjang karir agen mendapatkan premi asuransi maksimal 10 per/bulan.

Tabel 1.20 Daftar Produktivitas Agen Bulan Oktober 2017 DAFTAR PRODUKTIVITAS AGEN OKTOBER 2017

\begin{tabular}{|c|c|c|c|c|c|c|c|c|c|c|}
\hline \multirow{3}{*}{\multicolumn{2}{|c|}{$\begin{array}{l}\text { KANTOR } \\
\text { AGEN } \\
\text { PERIODE MULAI ASURANSI }\end{array}$}} & \multicolumn{9}{|c|}{ : KANTOR PEMASARAN SYARIAH PALEMBANG } \\
\hline & & \multicolumn{9}{|l|}{ : SELURUH AGEN } \\
\hline & & \multicolumn{9}{|c|}{ : 01 OKTOBER S.D 31 OKTOBER 2017} \\
\hline No. & NAMA AGEN & NOMOR KANTOR & NAMA KANTOR & \multicolumn{6}{|c|}{ JENIS ASURANSI } & $\begin{array}{c}\text { JUMLAH PREMI } \\
\text { BRUTO } \\
\end{array}$ \\
\hline & & & & & & & & & & \\
\hline 1 & Wakalah I & 3040700 & $\begin{array}{l}\text { Kantor Pemasaran } \\
\text { Syariah Palembang }\end{array}$ & 0 & 0 & 0 & 0 & 0 & 0 & 0,00 \\
\hline 3 & Wakalah III & 3040700 & $\begin{array}{l}\text { Kantor Pemasaran } \\
\text { Syariah Palembang }\end{array}$ & 0 & 0 & 0 & 0 & 0 & 0 & 0,00 \\
\hline 4 & Wakalah IV & 3040700 & $\begin{array}{l}\text { Kantor Pemasaran } \\
\text { Syariah Palembang }\end{array}$ & 0 & 0 & 0 & 0 & 0 & 0 & 0,00 \\
\hline 5 & Wakalah V & 3040700 & $\begin{array}{l}\text { Kantor Pemasaran } \\
\text { Syariah Palembang }\end{array}$ & 1 & 0 & 0 & 0 & 0 & 0 & $300.000,00$ \\
\hline \multirow{6}{*}{ No. } & MITRA IQRA PLUS & MIP & & & & & & & & \\
\hline & MITRA MABRU PLUS & MMP & & & & & & & & \\
\hline & MITRA BP LINK SYARIAH & BP LINK & & & & & & & & \\
\hline & & ASSALAM & & & & & & & & \\
\hline & & TA'AWUN & & & & & & & & \\
\hline & & ASKUM & & & & & & & & \\
\hline
\end{tabular}

Daftar Tabel di atas menggambarkan bahwa produktivitas agen yang memasarkan produk asuransi, di bulan Oktober terjual tujuh produk, yaitu jenis 
asuransi Mitra BP Link Syariah Assalam sebesar Rp. 1.700.000,00. Syarat untuk jenjang karir agen mendapatkan premi asuransi maksimal 10 per/bulan.

Tabel 1.21 Daftar Produktivitas Agen Bulan November 2017 DAFTAR PRODUKTIVITAS AGEN NOVEMBER 2017

\begin{tabular}{|c|c|c|c|c|c|c|c|c|c|c|}
\hline \multicolumn{2}{|c|}{$\begin{array}{l}\text { KANTOR } \\
\text { AGEN } \\
\text { PERIODE MULAI ASURANSI }\end{array}$} & $\begin{array}{l}\text { : KANTOR PEMAS } \\
\text { : SELURUH AGEN } \\
: 01 \text { NOVEMBER S. }\end{array}$ & $\begin{array}{l}\text { ARAN SYARIAH PALEI } \\
. \text { D } 30 \text { NOVEMBER } 201\end{array}$ & ANG & & & & & & $\begin{array}{l}\text { : SELURUH AGEN } \\
\text { :01 NOVEMBER S.D } 30 \text { NOVEMBER } 2017\end{array}$ \\
\hline \multirow{2}{*}{ No. } & \multirow{2}{*}{ NAMA AGEN } & \multirow{2}{*}{ NOMOR KANTOR } & \multirow{2}{*}{ NAMA KANTOR } & \multicolumn{6}{|c|}{ JENIS ASURANSI } & \multirow{2}{*}{$\begin{array}{l}\text { JUMLAH PREMI } \\
\text { BRUTO }\end{array}$} \\
\hline & & & & MIP & MMP & BP LINK & ASSALAM & TA'AWUN & ASKUM & \\
\hline 1 & Wakalah I & 3040700 & \begin{tabular}{|l|} 
Kantor Pemasaran \\
Syariah Palembang
\end{tabular} & 2 & 0 & 0 & 1 & 0 & 0 & $1.500 .000,00$ \\
\hline 2 & Wakalah II & 3040700 & $\begin{array}{l}\text { Kantor Pemasaran } \\
\text { Syariah Palembang }\end{array}$ & 0 & 0 & 0 & 0 & 0 & 0 & 0,00 \\
\hline 3 & Wakalah III & 3040700 & $\begin{array}{l}\text { Kantor Pemasaran } \\
\text { Syariah Palembang }\end{array}$ & 1 & 0 & 0 & 0 & 0 & 0 & $1.200 .000,00$ \\
\hline 4 & Wakalah IV & 3040700 & \begin{tabular}{|l|} 
Kantor Pemasaran \\
Syariah Palembang
\end{tabular} & 0 & 0 & 0 & 0 & 0 & 0 & 0,00 \\
\hline \multirow[t]{2}{*}{5} & Wakalah V & 3040700 & $\begin{array}{l}\text { Kantor Pemasaran } \\
\text { Syariah Palembang }\end{array}$ & 0 & 0 & 0 & 6 & 0 & 0 & $300.000,00$ \\
\hline & \multicolumn{3}{|c|}{ JUMLAH } & 3 & 0 & 0 & 7 & 0 & 0 & $3.000 .000,00$ \\
\hline \multicolumn{11}{|c|}{ Catatan: } \\
\hline \multirow[t]{7}{*}{\begin{tabular}{|l|} 
No. \\
\end{tabular}} & JENIS ASURANSI & KODE & & & & & & & & \\
\hline & MITRA IQRA PLUS & MIP & & & & & & & & \\
\hline & MITRA MABRU PLUS & MMP & & & & & & & & \\
\hline & MITRA BP LINK SYARIAH & BP LINK & & & & & & & & \\
\hline & & ASSALAM & & & & & & & & \\
\hline & & TA'AWUN & & & & & & & & \\
\hline & & ASKUM & & & & & & & & \\
\hline
\end{tabular}

Daftar Tabel di atas menggambarkan bahwa produktivitas agen yang memasarkan produk asuransi, di bulan Oktober terjual tujuh produk, yaitu jenis asuransi Mitra BP Link Syariah Assalam sebesar Rp. 3.000.000,00. Syarat untuk jenjang karir agen mendapatkan premi asuransi maksimal 10 per/bulan.

Tabel 1.22 Daftar Produktivitas Agen Bulan Desember 2017 DAFTAR PRODUKTIVITAS AGEN DESEMBER 2017

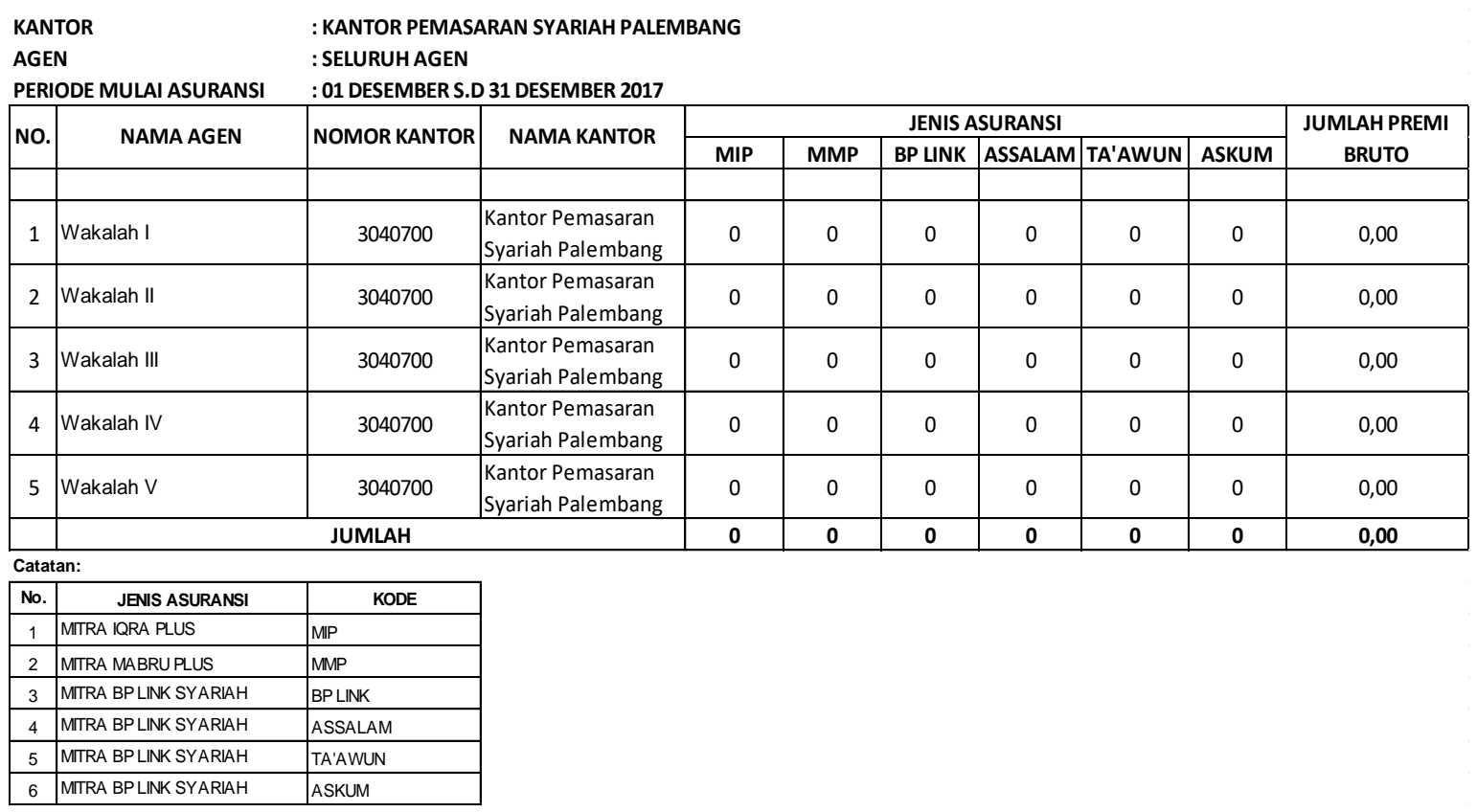


Daftar Tabel di atas menggambarkan bahwa produktivitas agen yang memasarkan produk asuransi, di bulan Desember terjual sepuluh produk, yaitu jenis asuransi Mitra BP Link Syariah Assalam sebesar Rp. 0,00. Syarat untuk jenjang karir agen mendapatkan premi asuransi maksimal 10 per/bulan.

Dari kesimpulan tabel laporan produktif agen terkait pemasaran produk diatas bahwa sumber daya manusia/agen Asuransi Jiwa Bumi Putera Syariah belum menggambarkan bahwa sumber daya manusia belum maksimal dalam memasarkan produk asuransi tersebut, bisa juga dikatakan belum berkompetensi dan belum profesional dalam menyikapi permasalahan yang ada dikarenakan dari laporan produktif agen perbulannya tidak mencapai target yang telah ditentukan oleh perusahaan.

\section{Kesimpulan}

Kompetensi sumber daya manusia yang dalam hal ini fokus penelitian pada kompetensi agen (wakālah) pada perusahaan asuransi syariah Bumi Putera di kota Palembang. Hasilnya adalah didapatkan bahwa dari kesimpulan enam indikator dan dibuktikan dengan tabel laporan produktif agen terkait pemasaran produk bahwa sumber daya manusia pada agen/wakālah Asuransi Jiwa Bumi Putera Syariah belum menggambarkan berkompetensi dan profesional. Hal ini terlihat minimnya produk asuransi yang terjual, penyikapan permasalahan lapangan dan belum tercapainya target nasabah yang ditentukan oleh perusahaan.

Kepada perusahaan asuransi syariah khususnya perusahaan Bumi Putera Syariah untuk meningkatkan kompetensi sumber daya manusia terkhusus para wakālah melalui training kemampuan agency yang tidak hanya mengejar nasabah, akan tetapi dari segi keilmuan asuransi syariah yang profesional dan islami.

\section{Daftar Rujukan}

Alexander, Gregorius C. "Pentingnya Rasa Percaya Diri dalam Dunia Kerja" dalam https://marketing.co.id.

Anoraga, Pandji. Pengantar Bisnis: Pengelolaan Bisnis dalam Era Globalisasi. Jakarta: Rineka Cipta, 2007.

Cardoso, Gomes Faustino. Manajemen Sumber Daya Manusia. Yogyakarta: Andi, 2003.

Danang, Sunyoto. Manajemen Sumber Daya Manusia. Yogyakarta: Caps, 2012.

Darwin, Steven dan Yohanes Sondang Kunto. "Analisis Pengaruh Kualitas Layanan Terhadap Loyalitas Pelanggan dengan Kepuasan dan Kepercayaan Pelanggan Sebagai Variabel Intervening pada Asuransi Jiwa Manulife Indonesia-Surabaya". Jurnal Manajemen Pemasaran Petra, Vol 2, No.1 2014.

Iriyanto. Human Resouce and Development. Surabaya: Insan Cendikia, 2001.

J, Bhatnagar. dan A Sharma. "The Indian Perspective of Strategic HR Roles and Organizational Learning Capability”. Int. J. Hum. Res. Manage, Vol. 16, No. 9, 2005.

Lako, Andreas, dan Anna Sumaryati. "Optimalisasi Kinerja Korporasi Melalui Audit Kinerja Manajemen Sumber Daya Manusia". Manajemen Usahawan Indonesia, No. 10 Th September, 2002.

Mahfuz. "Perkembangan Ekonomi Syariah dan Peran Sertanya dalam Pembangunan 
Indonesia dalam http://www.globalmulia.ac.id.

Malayu, Hasibuan. Manajemen Sumber Daya Manusia. Jakarta: Bumi Aksara. 2001.

Manan, Abdul. Hukum Ekonomi Syariah dalam Perspektif Kewenangan Peradilan Agama. Jakarta: Kencana Prenada Media Grup, 2012.

Moenir. Manajemen Pelayaan Umum di Indonesia. Jakarta: Bumi Aksara, 1995.

Narimawati, Umi. Riset Manajemen Sumber Daya Manusia. Jakarta: Agung Media, 2007.

P. Siagian, Sondang. Manajemen Sumber Daya Manusia. Jakarta: Bumi Aksara, 2008.

Parkinson, Mark. Panduan Sukses Menghadapi Tes Psikometri (Psychometric Test). Solo: Tiga Serangkai, 2004.

Rahmasari, Lisda. "Pengaruh Kecerdasan Intelektual, Kecerdasan Emosi dan Kecerdasan Spiritual Terhadap Kinerja Karyawan”. Majalah Ilmiah INFORMATiKA, Vol. 3 No. 1, Januari 2012.

Ramadhani, Herry. "Prospek dan Tantangan Perkembangan Asuransi Syariah di Indonesia". AL-TIJARY, Vol. 01, No. 01, Desember 2015.

Robert L, Mathis dan John H Jackson. Manajemen Sumber Daya Manusia, Buku I. Jakarta: Salemba Empat, 2001.

Sadili, Samsudin. Manajemen sumber Daya Manusia. Bandung: Pustaka Setia, 2006.

Siswanto, Sastrohadiwiryo. Manajemen Tenaga Kerja Indonesia. Jakarta: Bumi Aksara, 2003.

Sudarsono. Bank dan Lembaga Keuangan Syariah. Yogyakarta: Ekonisia, 2004.

Yusuf, Burhanuddin dan Al Arif Nur Rianto. Manajemen Sumber Daya Manusia di Lembaga Keuangan Syariah. Jakarta: Raja Grafindo Persada, 2015. 